\title{
Some Factors Controlling the Attachment of the Rumen Holotrich Protozoa Isotricha intestinalis and I. prostoma to Plant Particles in vitro
}

\author{
By COLIN G. ORPIN AND ANDREW J. LETCHER \\ Department of Biochemistry, \\ Agricultural Research Council, Institute of Animal Physiology, \\ Babraham, Cambridge CB2 $4 A T$
}

(Received 27 October 1977; revised 19 December 1977)

\begin{abstract}
The rumen holotrich protozoa Isotricha intestinalis and I. prostoma showed chemotaxis to sucrose, glucose and fructose. They attached themselves, by means of an organelle on the anterior cell surface, to particulate sources of these carbohydrates provided soluble protein was present in the medium. The concentration of protein eliciting attachment varied with the species and the state of nutrition of the cell, but was between 20 and $150 \mu \mathrm{g} \mathrm{ml}^{-1}$. Attachment occurred only if the concentration of carbohydrate, at its source, exceeded the chemotaxis threshold concentration (50 $\mu \mathrm{M}$ for sucrose) and if it was less than $1 \mathrm{~mm}$. At concentrations exceeding $1 \mathrm{~mm}$, indiscriminate attachment to gas-liquid and solid-liquid interfaces occurred, provided the protein concentration was high enough to elicit attachment. In the rumen, soluble carbohydrates diffusing from food particles may attract the protozoa which attach themselves to the particles in the presence of soluble plant protein at $>20 \mu \mathrm{g} \mathrm{ml}^{-1}$; these conditions exist in the host animal soon after feeding when fed infrequently. The attachment mechanism may confer an ecological advantage on the Isotricha spp. over other rumen organisms dependent on soluble carbohydrates as energy and carbon sources.
\end{abstract}

\section{INTRODUCTION}

The rumen holotrich protozoon Isotricha intestinalis Stein possesses an organelle situated on the anterior dorsilateral surface which is used for the attachment of the cell to fresh plant particles in vitro (Orpin \& Hall, 1977). The organelle is a longitudinal ridge, 24 to $37 \mu \mathrm{m}$ long and about $5 \mu \mathrm{m}$ wide, terminating at, or close to, the anterior end of the cell. The ridge consists of cytoplasmic projections from the cell surface; underlying the plasma membrane is a sheet of microtubules (Orpin \& Hall, 1977). We have observed a similar organelle having the same function on the anterior of $I$. prostoma Stein.

Isotricha intestinalis and I. prostoma are not commonly observed attached to particulate material present in rumen fluid and their attachment in large numbers to fresh plant particles in vitro suggested that a property of the fresh tissue or the environmental conditions encouraged this association. We have investigated the conditions under which attachment occurs.

\section{METHODS}

Sheep. Clun Forest wethers were used, each fitted with a permanent rumen cannula and fed $1 \mathrm{~kg}$ hay chaff and $100 \mathrm{~g}$ rolled oats once daily. Defaunation was according to Orpin (1977a).

Protozoa. Isotricha intestinalis and I. prostoma were cultured separately in vivo in the rumen of sheep devoid of other rumen holotrich protozoa. Two weeks after defaunation each rumen was inoculated with 
about 100 cells of one species (picked by micromanipulator from fresh rumen fluid from a sheep with a normal protozoal population): 3 to 5 weeks later the protozoa were seen in samples of rumen fluid examined microscopically. After a further 2 to 4 weeks, the population density was sufficient for the protozoa to be harvested either by differential centrifugation (speed and time varied for each batch of rumen fluid) under $\mathrm{CO}_{2}$ at room temperature in the salts solution of Sugden \& Oxford (1952) (nutritionally deplete) or replete with storage polysaccharide ('fed' cells) by the method of Orpin (1977a). Cells for chemotaxis and attachment experiments were resuspended in reduced centrifuged rumen fluid (autoclaved rumen fluid supernatant containing $0.1 \%(\mathrm{w} / \mathrm{v})$ L-cysteine hydrochloride; Orpin, $1977 \mathrm{~b}$ ) and maintained at $39^{\circ} \mathrm{C}$ under $\mathrm{CO}_{2}$. Cells were fixed for microscopy with $2 \%$ formalin.

Plant materials. Perennial rye-grass (Lolium perenne) was obtained from the Institute farm. Soluble material was removed from the tissues by diffusion into distilled water (Orpin \& Bountiff, 1978). Barley (Hordeum distichon) plants were kindly supplied by Dr A. A. Jenkins, Agricultural Research Council, Plant Breeding Institute, Trumpington, Cambridge. Cellulose, prepared from mixed gasses by the method of Jermyn (1955), was kindly supplied by Dr G. S. Coleman of this Institute.

Chemotaxis experiments. Chemotaxis chambers, similar to that designed by Adler (1973), each contained $0.2 \mathrm{ml}$ of a suspension of protozoa $\left(1.5 \times 10^{3}\right.$ cells $\left.\mathrm{ml}^{-1}\right)$ in reduced centrifuged rumen fluid. The compound under examination was dissolved in $\mathrm{CO}_{2}$-saturated reduced centrifuged rumen fluid, and taken up in a capillary (20 $\mu \mathrm{l}$ Drummond microcap; Drummond Scientific Co., U.S.A.), one end of which was sealed with latex. The other end of the capillary was immersed in the cell suspension in the chemotaxis chamber, the coverslip was sealed with vaseline to prevent oxygen entry, and the chamber was incubated at $39^{\circ} \mathrm{C}$ for $30 \mathrm{~min}$. The contents of each capillary were then expressed on to a microscope slide and the total number of protozoa which had entered the tube were counted. Results were corrected for random entry of protozoa into control tubes which contained only reduced centrifuged rumen fluid.

Estimation of attachment to particulate material. Fresh plants were separated into leaf, ligule, stem and inflorescence tissues. Each tissue was cut into pieces about $5 \times 1 \mathrm{~mm}$ and four such pieces were placed in a $1 \mathrm{~mm}$ deep chamber on a microscope slide. A suspension of protozoa $\left(0.2 \mathrm{ml}, 1.5 \times 10^{3} \mathrm{cells} \mathrm{ml}^{-1}\right)$ in reduced centrifuged rumen fluid was added, and then the chamber was covered with a coverslip and sealed with vaseline to restrict oxygen access. The coverslip pressed on to the grass particles such that access by the protozoa was only possible at the sides and ends of the particles. The slide was incubated $\left(39^{\circ} \mathrm{C}, 20 \mathrm{~min}\right)$ and examined using an inverted microscope with a heated $\left(39^{\circ} \mathrm{C}\right)$ stage. The number of cells attached to the tissue was counted and expressed as a percentage of the total cells added. Because of variation in the initial number of protozoa added, due to pipetting discrepancies, each experiment was performed several times. Experiments with grass cellulose were performed similarly.

Protein. Protein was determined by the biuret method of Gornall, Bardawill \& David (1949). Plant fraction 1 protein (PF1P: ribulose-1,5-bisphosphate carboxylase; EC 4.1.1.39) was donated by Mr J. A. Nugent of these laboratories.

Calf serum was denatured by diluting $3: 1$ with distilled water and heating $\left(100^{\circ} \mathrm{C}, 15 \mathrm{~min}\right)$. The denatured protein was sedimented by centrifugation $(2500 \mathrm{~g}$, room temperature, $10 \mathrm{~min})$ and the supernatant $(30 \%$, $\mathrm{v} / \mathrm{v})$ was used to replace the serum in the attachment medium.

\section{RESULTS}

Isotricha intestinalis (Fig. 1) became attached to particles of perennial rye-grass tissue, suspended in a complex medium, by means of the attachment organelle situated on the anterior dorsilateral surface of the cell (Figs 1 and 2). By selective removal of the medium constituents, a minimal medium was formulated in which the protozoa still showed attachment to the grass particles (Figs 3 and 4). This medium contained (in $100 \mathrm{ml}$, final volume): centrifuged autoclaved rumen fluid, $10.0 \mathrm{ml}$; inactivated calf serum, $10.0 \mathrm{ml}$; L-cysteine hydrochloride, $0.1 \%(\mathrm{w} / \mathrm{v})$; and was saturated with $\mathrm{CO}_{2}$. When the rumen fluid was replaced by the salts solution of Sugden \& Oxford (1952), attachment still occurred but to a lesser degree (Table 1). Little attachment occurred in the absence of the serum or L-cysteine. In the absence of serum, the cells had a normal appearance and were actively motile; in the absence of L-cysteine, the motility decreased and the cells may have been affected by the change in redox potential. These results showed that a component in the serum was essential for attachment to occur. Fed cells, containing large polysaccharide reserves, showed considerably less association with the grass particles (Table 1). In addition to the attachment of cells by the region of the dorsilateral ridge, penetration 
Table 1. Effect of medium constituents and nutritional status of cells on attachment of Isotricha intestinalis and I. prostoma to leaf tissue of perennial rye-grass

Results indicate the percentage of the total cells present that were attached to the leaf tissue after incubation for $20 \mathrm{~min}$ at $39^{\circ} \mathrm{C}$. Average of four experiments.

\begin{tabular}{|c|c|c|c|c|}
\hline \multirow[b]{3}{*}{ Medium* } & \multicolumn{4}{|c|}{ Cells attached $(\%)$} \\
\hline & \multicolumn{2}{|c|}{ I. intestinalis } & \multicolumn{2}{|c|}{ I. prostoma } \\
\hline & Deplete & Fed & Deplete & Fed \\
\hline CARF & 0 & 0 & 0 & 0 \\
\hline CARF + L-cysteine & 2 & 0 & 1 & 0 \\
\hline CARF + serum & 0 & 0 & 0 & 0 \\
\hline CARF + L-cysteine + serum & 32 & 15 & 28 & 6 \\
\hline Salts + L-cysteine + serum & 24 & 13 & 20 & 6 \\
\hline
\end{tabular}

* CARF, Centrifuged autoclaved rumen fluid supernatant; L-cysteine, L-cysteine hydrochloride, incorporated at $0 \cdot 1 \%(\mathrm{w} / \mathrm{v})$; serum, inactivated calf serum, incorporated at $10 \%(\mathrm{v} / \mathrm{v})$; salts, salts solution of Sugden \& Oxford (1952); the atmosphere was $\mathrm{CO}_{2}$.

of the plant tissue through fractures in the surface was observed (Fig. 5). No attachment occurred if the water-soluble components of the leaf tissue had been removed.

Similar results were obtained with Isotricha prostoma (Table 1) which also possessed an attachment organelle up to $45 \mu \mathrm{m}$ long and $7 \mu \mathrm{m}$ wide on the anterior portion of the cell (Fig. 6).

\section{External protein concentration}

Since a component of calf serum was essential for attachment to occur, other inactivated sera and soluble proteins were examined for their ability to induce the attachment of I. intestinalis. Attachment was not affected by the type of inactivated serum used (sheep, calf or horse) and it occurred at a similar level when the serum was replaced by bovine serum albumin or bovine $\gamma$-globulins (at $200 \mu \mathrm{g} \mathrm{ml}^{-1}$ ) but not when replaced by tryptone (at $0.1 \%, w / v$ ). Denatured serum supernatant fluid, however, induced only about $20 \%$ of the attachment shown with whole serum, suggesting that the intact serum proteins were responsible for inducing attachment.

Mastication of fresh plant tissue by the ruminant releases up to $50 \%$ of the soluble cell protein into the bolus (Reid, Lyttleton \& Mangan, 1962) where the concentration of soluble protein may reach $100 \mu \mathrm{g} \mathrm{ml}^{-1}$. The major protein released into the bolus is plant fraction 1 protein, so the effect of this protein on the attachment of nutritionally deplete I. intestinalis to perennial rye-grass leaf tissue was examined (Fig. 8). Attachment was initiated by as little as $20 \mu \mathrm{g} \mathrm{PF1P} \mathrm{ml} l^{-1}$, and reached a maximum at $>100 \mu \mathrm{g} \mathrm{ml}^{-1}$. The effect was less with fed cells, attachment being initiated at 40 to $50 \mu \mathrm{g}$ protein $\mathrm{ml}^{-1}$ and reaching a maximum at $120 \mu \mathrm{g} \mathrm{ml}^{-1}$. Similar results were obtained with $I$. prostoma, but the maximum proportion of cells attached at any time at the optimum protein concentration ( $>120 \mu \mathrm{g} \mathrm{ml}^{-1}$ ) was only $35 \%$ compared with $56 \%$ for I. intestinalis.

\section{Attachment to different plant tissues}

Attachment occurred equally to perennial rye-grass leaf, ligule and inflorescence tissues when offered singly (Table 2): little attachment to stem tissue was recorded. If ligule and leaf tissue or inflorescence and leaf tissue (easily distinguished by microscopy) were offered together, attachment occurred principally to the ligule or inflorescence tissue rather than to the leaf tissue. No preference was detected between ligule and inflorescence tissues. Similar results were shown when tissues from barley were used. 

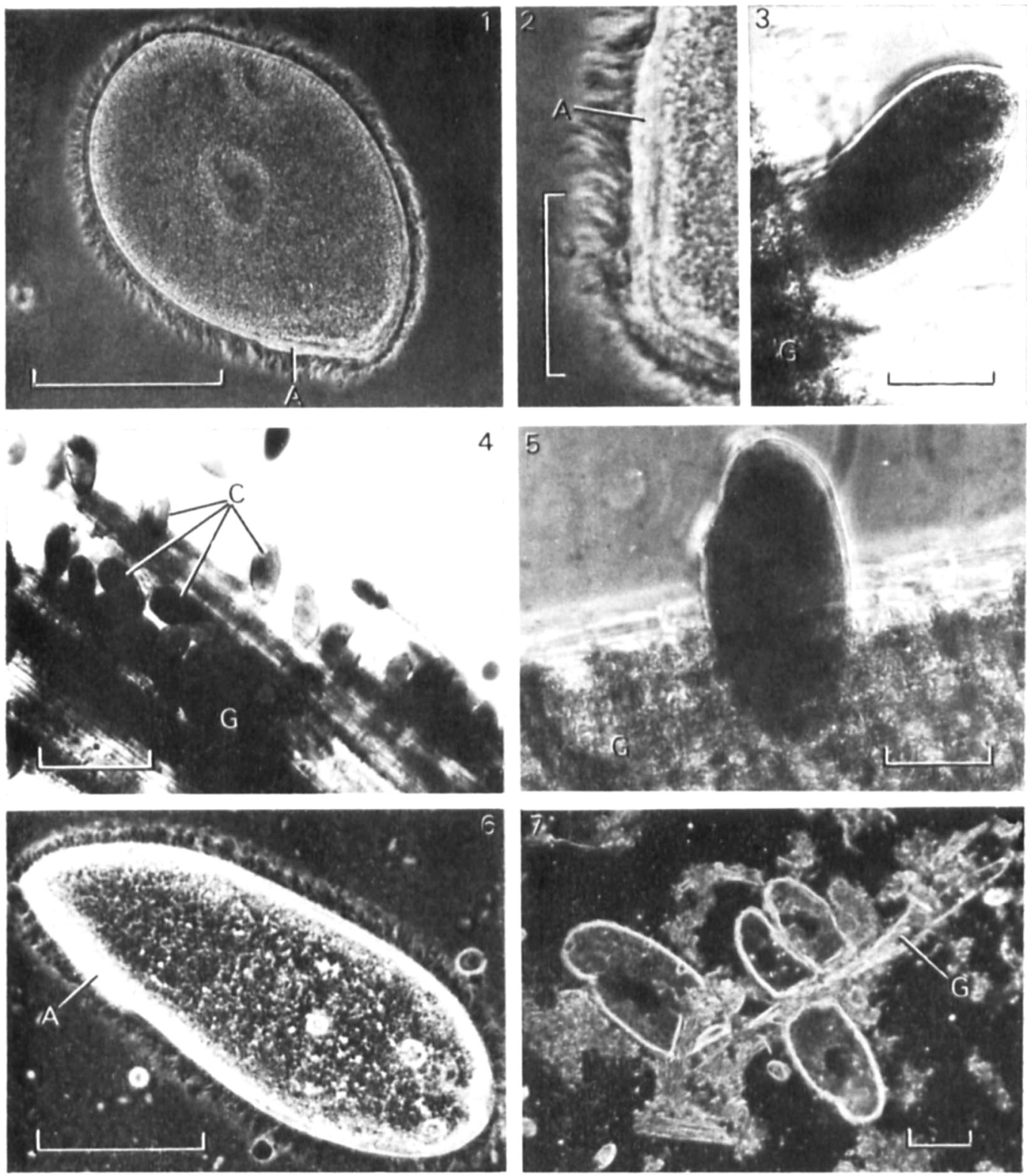

Bar markers represent $50 \mu \mathrm{m}$ in Figs 1, 3, 5,6 and 7, $20 \mu \mathrm{m}$ in Fig. 2 and $250 \mu \mathrm{m}$ in Fig. 4.

Figs 1 and 2. Attachment organelle in I. intestinalis, situated on the anterior dorsilateral cell surface. (Fig. 2 shows an enlargement of the attachment organelle region of the cell in Fig. 1.)

Figs 3 and 4. Attachment of I. intestinalis to perennial rye-grass leaf tissue in vitro.

Fig. 5. Penetration of perennial rye-grass leaf tissue, which extends behind the prctruding portion of the I. intestinalis cell.

Fig. 6. Attachment organelle in I. prostoma.

Fig. 7. Attachment of four $I$. intestinalis cells to a plant particle in rumen fluid taken $1 \mathrm{~h}$ after feeding the host sheep.

Figs 1,2 and 6 are preparations fixed with $2 \%$ formalin; Figs 3, 4, 5 and 7 are living preparations. Photographs were taken with phase contrast illumination except Fig. 4 (bright field) and Fig. 7 (dark ground).

A, Attachment organelle; C, protozoon cell; G, leaf tissue. 


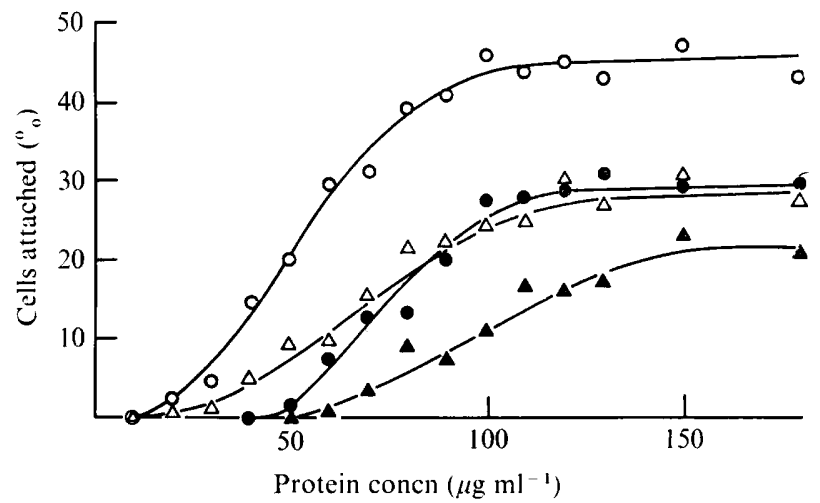

Fig. 8. Effect of plant fraction 1 protein (PF1P) on the attachment of Isotricha intestinalis and I. prostoma to perennial rye-grass tissue. A suspension of protozoa in reduced centrifuged rumen fluid $\left(0.2 \mathrm{ml}, 1.5 \times 10^{3}\right.$ cells $\left.\mathrm{ml}^{-1}\right)$ containing 0 to $180 \mu \mathrm{g} \mathrm{PF} 1 \mathrm{P} \mathrm{m}{ }^{-1}$ was added to a chamber containing perennial rye-grass leaf tissue (four pieces, each $5 \times 1 \mathrm{~mm}$ ). The chamber was incubated anaerobically $\left(39^{\circ} \mathrm{C}, 20 \mathrm{~min}\right)$, and the number of cells attached to the leaf tissue was counted and expressed as a percentage of the total cells added:, I. intestinalis, fed; $\bigcirc$, I. intestinalis, deplete; $\Delta, I$. prostoma, fed; $\triangle$, I. prostoma, deplete. Average of three experiments.

\section{Table 2. Attachment of nutritionally deplete Isotricha intestinalis and I. prostoma to different tissues of perennial rye-grass}

Results indicate the percentage of the total cells present that were attached to the tissue after incubation for $20 \mathrm{~min}$ at $39^{\circ} \mathrm{C}$. Average of four experiments.

\begin{tabular}{lcc} 
& \multicolumn{2}{c}{ Cells attached (\%) } \\
\cline { 2 - 3 } Tissue & I. intestinalis & I. prostoma \\
Leaf $:$ & 32 & 25 \\
Ligule & 44 & 49 \\
Stem & 10 & 12 \\
Inflorescence & 38 & 45 \\
Leaf + ligule & 10 leaf, 33 ligule & - \\
Leaf + inflorescence & 8 leaf, 31 inflorescence & - \\
Ligule + inflorescence & 20 ligule, 23 inflorescence & -
\end{tabular}

Table 3. Chemotaxis of nutritionally deplete Isotricha intestinalis and I. prostoma to sucrose, glucose and fructose

The threshold concentration is the minimum concentration tested which elicited chemotaxis. The optimum concentration is that concentration which attracted most cells per unit time.

$\begin{array}{lccccc}\text { Carbohydrate } & \overbrace{\begin{array}{c}\text { Threshold } \\ \text { concn }(\mu \mathrm{M})\end{array}}^{\text {I. intestinalis }} & \begin{array}{c}\text { Optimum } \\ \text { concn }(\mathrm{mM})\end{array} & \begin{array}{c}\text { Threshold } \\ \text { concn }(\mu \mathrm{M})\end{array} & \begin{array}{c}\text { Optimum } \\ \text { concn }(\mathrm{mM})\end{array} \\ \text { Sucrose } & 50 & 1 & 50 & 5 \\ \text { Glucose } & 50 & 1 & 10 & 1 \\ \text { Fructose } & 10 & 50 & 50 & 50\end{array}$

\section{Chemotaxis}

Inflorescence and ligule tissues are known to contain higher soluble carbohydrate levels than other tissues of the same plant in the family Gramineae (Forde et al., 1976; Orpin \& Bountiff, 1978), so chemotaxis to the major soluble carbohydrates - sucrose, glucose and fructose (Bailey, 1964) - found in perennial rye-grass tissues was investigated. Chemotaxis occurred with both species of protozoa to all three carbohydrates, with threshold concentrations as low as $50 \mu \mathrm{M}$ with sucrose (both species) and glucose (I. intestin- 


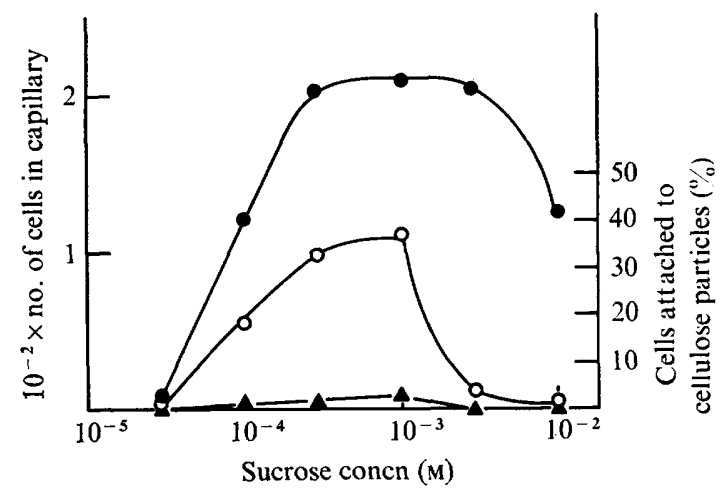

Fig. 9. Chemotaxis to sucrose by Isotricha intestinalis, and attachment to grass cellulose impregnated with sucrose.

In the chemotaxis experiments (O), the chemotaxis chamber contained $0.2 \mathrm{ml}$ of a suspension of protozoa $\left(1.5 \times 10^{3}\right.$ cells $\left.\mathrm{ml}^{-1}\right)$ in reduced centrifuged rumen fluid. The capillary contained sucrose dissolved in reduced centrifuged rumen fluid identical to that used to resuspend the cells. The chamber was incubated at $39^{\circ} \mathrm{C}$ for $3 \mathrm{~min}$. The contents of the capillary were then expressed on to a microscope slide, and the total number of protozoa was counted. Results are corrected for the random entry of protozoa into control tubes which contained only reduced centrifuged rumen fluid.

In the attachment experiments, a suspension of protozoa in reduced centrifuged rumen fluid $\left(0.2 \mathrm{ml}, 1.5 \times 10^{3}\right.$ cells $\left.\mathrm{ml}^{-1}\right)$, without added protein $(\Delta)$ or with $150 \mu \mathrm{g}$ bovine serum albumin $\mathrm{ml}^{-1}(\bigcirc)$, was added to a chamber containing grass cellulose impregnated with different concentrations of sucrose. The chamber was incubated anaerobically $\left(39^{\circ} \mathrm{C}, 20 \mathrm{~min}\right)$, and the number of cells attached to the cellulose was counted and expressed as a percentage of the total cells added.

alis) (Table 3). The effect of sucrose concentration on chemotaxis in $I$. intestinalis is shown in Fig. 9. Increasing the concentration of sucrose from the threshold $(50 \mu \mathrm{M})$ to $0.5 \mathrm{~mm}$ resulted in increased chemotaxis; between $0.5 \mathrm{~mm}$ and $5 \mathrm{~mm}$ there was no change, but at $10 \mathrm{~mm}$ many of the cells entering the capillary lysed, resulting in a drop in the number of intact cells by the end of the experiment.

\section{Attachment to cellulose}

No attachment of either species to purified grass cellulose occurred, even in the presence of bovine serum albumin at $150 \mu \mathrm{g} \mathrm{ml}^{-1}$. When the cellulose was impregnated with sucrose, glucose or fructose at concentrations in excess of the threshold concentration for chemotaxis, and bovine serum albumin $\left(150 \mu \mathrm{g} \mathrm{ml}^{-1}\right)$ was incorporated into the external medium, attachment of $I$. intestinalis was demonstrated. The degree of attachment varied with the concentration of the carbohydrate solution with which the cellulose was impregnated (Fig. 9), but at sucrose concentrations above $1 \mathrm{~mm}$ a decrease in attachment was recorded and many of the protozoa in the surrounding medium had attached themselves to the surface of the microscope slide or to gas-liquid interfaces. This was not observed with glucose or fructose at the same concentrations. Similar results were found with I. prostoma, except that no attachment to gas-liquid interfaces was observed.

\section{Attachment in vivo}

The conditions in vitro which resulted in maximum attachment to particulate material (low nutritional status of the cells, presence of free protein in the external medium) would be expected to occur soon after the host animal had eaten in an animal fed infrequently. A direct microscopic examination of rumen fluid containing both $I$. intestinalis and $I$. prostoma was made during the first $5 \mathrm{~h}$ after feeding a sheep, fed once daily, to determine if attachment occurred in vivo. During the first 0.5 to $2.5 \mathrm{~h}$ after feeding, both species of 
protozoon were observed attached to plant particles (Fig. 7) in varying numbers. It was not possible to determine accurately the proportion of cells attached but in some samples up to $80 \%$ of the Isotricha spp. were attached to plant particles.

\section{DISCUSSION}

The holotrich protozoa rapidly assimilate several soluble carbohydrates with the deposition of intracellular reserves of amylopectin (Oxford, 1951; Gutierrez, 1955). The major soluble carbohydrates in the diet of a sheep fed perennial rye-grass are glucose, fructose and sucrose (Bailey, 1964), which may be fermented by I. intestinalis and I. prostoma and other rumen micro-organisms. Only $50 \%$ of the soluble cell contents are released into the bolus after mastication by the host animal (Reid et al., 1962), and the remainder may be released during cud chewing and by diffusion into the rumen fluid. Using the results of Phillipson \& McAnally (1942), the soluble carbohydrates released from perennial ryegrass $(1 \mathrm{~kg}$ at $12 \%$ dry matter and $9.5 \%$ hexoses and sucrose) would be metabolized within $0.76 \mathrm{~h}$ with residual concentrations during the remainder of the day of 0 to $0.018 \mathrm{~g} \mathrm{l}^{-1}$ (Ryan, 1964). The ability to respond chemotactically to residual soluble carbohydrate sources in dietary particles, and to maintain themselves in close contact with the source despite the gentle agitation (Orpin \& Hall, 1977) which occurs during the churning of the rumen contents, confers an ecological advantage on $I$. intestinalis and I. prostoma over other rumen micro-organisms dependent on soluble carbohydrates and not able to maintain themselves near the carbohydrate source without the expenditure of energy. Chemotaxis to soluble carbohydrates and plant tissue has also been described for the rumen phycomycete zoospores Neocallimastix frontalis and Piromonas communis (Orpin, 1977c; Orpin \& Bountiff, 1978) and may be a mechanism enhancing the chance of survival of rumen organisms which rely largely upon soluble carbohydrates as energy and carbon sources.

Chemotaxis to the source of the diffusing carbohydrate was, in itself, not sufficient for attachment to occur, and attachment occurred only in the presence of soluble protein. In the rumen, it is likely that positive chemotaxis in the gradient of soluble carbohydrates diffusing from the plant tissue occurs until the concentration of sucrose reaches more than $1 \mathrm{~mm}$, when attachment occurs to any interphase surface that is close. At lower sucrose concentrations, attachment occurs when the source of the diffusing carbohydrates is reached.

Attachment to solid surfaces has also been shown in the rumen entodiniomorphid protozoon Epidinium ecaudatum, which may become attached to rumen particulate material (Bauchop \& Clarke, 1976), but as yet no specialized attachment organelle has been described for this species. Epidinium ecaudatum may also respond chemotactically to soluble plant components diffusing from the tissues. The holotrich protozoon Dasytricha ruminantium adheres to glass, a phenomenon employed during the isolation of the species from rumen fluid (Gutierrez, 1955), but chemotaxis is unlikely to be involved and we have not observed any attachment organelle in living cells or cells fixed with formaldehyde examined by light microscopy.

We do not know if the organelle has any function other than the attachment of the cell to interphase surfaces. Nutrients, including soluble carbohydrates, may be absorbed through the organelle, or extracellular enzymes may be excreted through the organelle on to the plant particles. The mechanism of attachment is still obscure, but we do know that attachment and dissociation of the protozoa from the plant tissue occurs freely and frequently indicating that attachment is likely to be a purely physical phenomenon.

The attachment of the isotrichs to plant tissues during the first $2 \mathrm{~h}$ after feeding may partially explain the results of Weller \& Pilgrim (1974) who showed that the outflow of protozoa from the rumen appeared to follow the solid rather than the liquid phase of the rumen digesta. 
We thank Dr P. Kemp for cannulating the sheep.

\section{REFERENCES}

AdLeR, J. (1973). A method for measuring chemotaxis and use of the method to determine optimum conditions for chemotaxis by Escherichia coli. Journal of General Microbiology 74, 77-91.

BaILeY, R. W. (1964). Pasture quality and ruminant nutrition. I. Carbohydrate composition of ryegrass varieties grown as sheep pastures. New Zealand Journal of Agricultural Research 7, 496507.

Bauchop, T. \& Clarke, R. T. J. (1976). Attachment of the ciliate Epidinium Crawley to plant fragments in the sheep rumen. Applied and Environmental Microbiology 32, 417-422.

Forde, B. J., Slack, C. R., Roughan, P. G., Haslemore, R. M. \& MCLeod, M. N. (1976). Growth of tropical and temperate grasses at Palmerston North. II. Total nitrogen, soluble sugar, starch and in vitro digestibility determinations. New Zealand Journal of Agricultural Research 19, 489-498.

Gornall, A. G., Bardawill, C. J. \& David, M. M. (1949). Determination of serum proteins by means of the biuret reaction. Journal of Biological Chemistry 177, 751-766.

Gutierrez, J. (1955). Experiments on the culture and physiology of holotrichs from the bovine rumen. Biochemical Journal 60, 516-522.

Jermyn, M. A. (1955). Cellulose and hemicelluloses. In Modern Methods of Plant Analysis, vol. 2, pp. 197-225. Edited by K. Paech and M. V. Tracey. Berlin: Springer-Verlag.

OrPIN, C. G. (1977a). Studies on the defaunation of the ovine rumen using dioctyl sodium succinate. Journal of Applied Bacteriology 43, 309-318.

OrPIN, C. G. (1977 b). Invasion of plant tissue in the rumen by the flagellate Neocallimastix frontalis. Journal of General Microbiology 98, 423430.

OrPIN, C. G. $(1977 c)$. The rumen flagellate Piro- monas communis: its life-history and invasion of plant material in the rumen. Journal of General Microbiology 99, 107-117.

Orpin, C. G. \& BountifF, L. (1978). Zoospore chemotaxis in the rumen phycomycete Neocallimastix frontalis. Journal of General Microbiology 104, 113-122.

OrPIN, C. G. \& Hall, F. J. (1977). Attachment of the rumen holotrich protozoon Isotricha intestinalis to grass particles. Proceedings of the Society for General Microbiology 4, 82-83.

OXFORD, A. E. (1951). The conversion of certain soluble sugars to a glucosan by holotrich ciliates in the rumen of sheep. Journal of General Microbiology 5, 83-93.

Phillipson, A. T. \& McAnally, R. A. (1942). Studies on the fate of carbohydrates in the sheep rumen. Journal of Experimental Biology 19, 199214.

Reid, C. S. W., Lyttleton, J. W. \& Mangan, J. L. (1962). Bloat in cattle. XXIV. A method for measuring the effectiveness of chewing in the release of plant cell contents from ingested feed. New Zealand Journal of Agricultural Research 5, 237-248.

RYAN, R. K. (1964). Concentrations of glucose and low molecular-weight acids in the rumen of sheep changed gradually from hay to a hay-plus-grain ration. American Journal of Veterinary Research 25, 653-659.

Sugden, B. \& OXFord, A. E. (1952). Some cultural studies with holotrich ciliate protozoa of the sheep's rumen. Journal of General Microbiology 7, 145-153.

Weller, R. A. \& Pilgrim, A. F. (1974). Passage of protozoa and volatile fatty acids from the rumen of the sheep and from a continuous in vitro fermentation system. British Journal of Nutrition 24, 589-598. 